\title{
Post-operative Pain and Antibacterial Efficacy of Silver Nanoparticles Formulations Intracanal Medication: A Randomized Controlled Clinical Study
}

\author{
Nermine Hassan*(i), Alaa Diab, Geraldine Ahmed (D) \\ Department of Endodontics, Faculty of Dentistry, Cairo University, Giza, Egypt
}

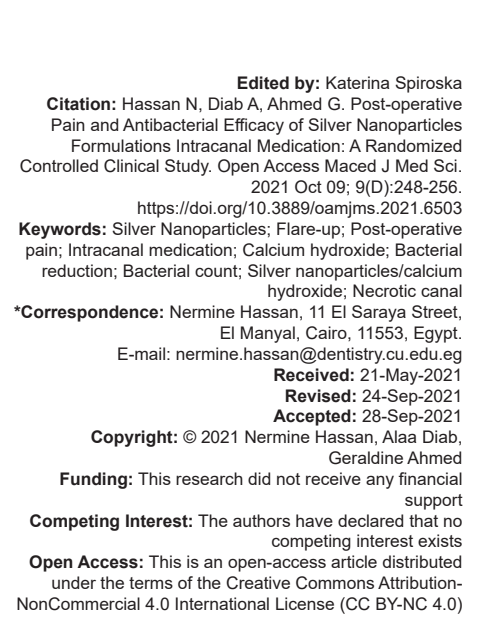

Abstract

AIM: This study aims to evaluate the effect of using combined calcium hydroxide $\left(\mathrm{Ca}(\mathrm{OH})_{2}\right) /$ silver nanoparticles (AgNPs) or $\mathrm{Ca}(\mathrm{OH})_{2}$ individually as intracanal medications in reducing post-operative pain and intracanal bacteria count.

MATERIALS AND METHODS: Thirty patients with necrotic mandibular anterior teeth were randomly divided into three groups; $\mathrm{Ca}(\mathrm{OH})_{2}+$ AgNPs or AgNPs gel (intervention groups) or $\mathrm{Ca}(\mathrm{OH})_{2}$ (control group). Patients received a standard 2-visit endodontic treatment and recorded their pain levels after 4, 24, 48, 72, and $96 \mathrm{~h}$ following the firs and second visit on a modified visual analog scale. Intracanal bacterial counts were assessed using culturing before and after instrumentation and intracanal medication. Outcome data were statistically analyzed using Kruskal-Wallis and Fisher's exact tests to compare between the groups and Friedman's test to assess the changes by time.

RESULTS: At $24 \mathrm{~h}$ interappointment, the incidence of pain was statistically significant $(p=0.005)$ as well as at $48 \mathrm{~h}$ $(p=0.001)$. There was a statistically significant difference between the mean percentage reduction of anaerobic bacterial counts in the three groups with the highest percentage in the $\mathrm{Ca}(\mathrm{OH})_{2}+$ AgNPs group at $98.9 \%$ followed by AgNPs group $98.5 \%$ and $\mathrm{Ca}(\mathrm{OH})_{2}$ at $85.3 \%(\mathrm{p}<0.001)$

CONCLUSIONS: Combined $\mathrm{Ca}(\mathrm{OH})_{2} /$ AgNPs reduced the intracanal bacterial counts significantly, but adversely affected the interappointment pain. Based on that finding, this combination should be tested in different concentrations with different ratios to reach the most effective combination that reduces pain with high antibacterial efficacy.

\section{Introduction}

Post-operative pain after endodontic treatment is an undesirable occurrence for both patients and clinicians. Although several factors have been suggested, microbial injury has been considered the most common cause [1]. Bacteria residing in areas of the root canals such as isthmuses, apical ramifications, deltas, and dentinal tubules may be left unaffected by disinfection procedures. Inadequate elimination of this bacteria allows for bacterial growth which can gain access to the periapical tissues and cause inflammation [2].

In 1920, Hermann was the first to suggest the use of calcium hydroxide $\left(\mathrm{Ca}(\mathrm{OH})_{2}\right)$ as an intracanal medication [3]. While it is the most commonly used intracanal medication, it failed in many cases to eliminate all bacteria from the dentinal tubules [4]. A debate regarding its influence on post-operative pain yielded no sufficient evidence to prove its effect [5], [6].

Lately, silver nanoparticles (AgNPs) have gained much attention due to their unique characteristics, which lead to being incorporated in various dental materials [7]. AgNPs seem to be potential antibacterial agents due to their large surface-to-volume ratios and surface structure which can be a valuable additive to endodontic materials [8], and specifically as an intracanal medication alone [9] or in combination with $\mathrm{Ca}(\mathrm{OH})_{2}$. This combination has shown noticeable ability to reduce the bacterial count in root canals contaminated with Enterococcus faecalis [10], [11], [12]. However, no clinical studies tested its effect on post-operative pain.

This clinical trial was conducted to evaluate post-operative pain after the use of combined $\mathrm{Ca}(\mathrm{OH})_{2} /$ AgNPs or AgNPs alone or $\mathrm{Ca}(\mathrm{OH})_{2}$ alone as intracanal medication, where the goal was to provide scientific basis for treatment and to provide materials which could minimize post-operative pain and effectively eradicate root canal infection. The null hypothesis tested was that in patients with necrotic pulp, there is no difference in using combined $\mathrm{Ca}(\mathrm{OH})_{2}+$ AgNPs or AgNPs alone as intracanal medication in reducing post-operative pain and intracanal bacterial count as $\mathrm{Ca}(\mathrm{OH})_{2}$. 


\section{Materials and Methods}

\section{Ethical approval and protocol registration}

The study proposal was approved by the Research Ethics Committee (Ref. no. 15/10/18) and registered in Clinical Trials Registry (NCT03692286). The study reporting followed the Consolidated Standards of Reporting Trials (CONSORT) guidelines.

\section{Trial design and setting}

This study was a prospective, 3-arm, parallel group with an equal allocation ratio, double-blind, randomized controlled clinical trial and was conducted in accordance with the Helsinki Declaration of 1975, as revised in 2000. A written informed consent was obtained from each patient who kept a copy. This study took place in the outpatient endodontics clinic of Faculty of Dentistry, Cairo University, from June 2019 to August 2020 by the same operator.

\section{Sample size calculation}

The sample size was based on a previous study [13], the estimated difference in post-operative pain at $4 \mathrm{~h}$ was $3 \pm 3$ on a visual analog scale (VAS) from 0 to 10 . Using type I error of 0.05 , and statistical power of $80 \%$, the required sample size was 18 participants, which was increased to 21 participants to compensate for losses during follow-up (25\% more than the calculated). To adjust for using a nonparametric test, the number was increased to 30 participants. Sample size calculation was performed using (Power and Sample Size Calculation software; Windows).

\section{Eligibility criteria}

Participants included were of age from 20 to 40 years with asymptomatic necrotic mandibular anterior teeth with fully formed roots having a single canal, with no periapical radiolucency or periapical lesions smaller than or equal to $2 \mathrm{~mm}$. This was confirmed with conebeam computed tomography scans acquired using (Planmeca Promax 3D; Planmeca).

Exclusion criteria included medically compromised patients, pregnant ladies, and patients who administrated analgesics or antibiotics $12 \mathrm{~h}$ preoperatively as well as teeth with greater than Grade I mobility or pocket depth $>5 \mathrm{~mm}$ or radiographic evidence of external or internal root resorption.

\section{concealment \\ Randomization and allocation}

Patients were assigned to one of three groups using a website (www.random.org). Allocation concealment was done through using sequentially numbered, opaque, and sealed envelopes that were opened at the time of intracanal medication placement.

\section{Blinding}

In this study, both the patients and outcome assessors were blinded to the treatment. Another investigator not involved in the study implemented the randomization and allocation concealment. The operator was not blinded due to the difference in the intracanal medication texture.

\section{Materials}

All the chemicals used in the study were of analytical grade (purity 95\%) and were purchased from (Sigma-Aldrich; Merck Group). AgNPs were prepared in gel form by mixing AgNPs powder of size $17 \mathrm{~nm}$ (Institute for Nanoscience and Nanotechnology; Egypt) with methylcellulose (MC; Alfa Chemistry). One gram of $\mathrm{MC}$ was added into $10 \mathrm{ml}$ of distilled water using a paste mixer (PDM-300; Daewha Tech). The solution mixture was heated to $70^{\circ} \mathrm{C}$ with continuous stirring [14]. The gel solution was left to cool to room temperature. Later, one gram of $50 \mathrm{ppm}$ AgNPs ( $0.03 \mu \mathrm{g} / \mathrm{ml}$ concentration) was added to the gel solution and stirred for $1 \mathrm{~h} \mathrm{[15].}$

For further assurance, characterization of the AgNPs was performed through transmission electron microscope (JEM-2100 TEM; JEOL) which revealed the formation of uniform spherical shape, with a narrow size distribution centered at approximately $17 \mathrm{~nm}$ (Figure 1a). The absorbance of the prepared solution that was measured spectrophotometrically (via DU-650 UV-Vis Spectrophotometer; Beckman) revealed a maximum peak of $405 \mathrm{~nm}$ indicating the presence of spherical AgNPs (Figure 1b).

To prepare the combined mixture, AgNPs gel was mixed with the readymade intracanal $\mathrm{Ca}(\mathrm{OH})_{2}$ injectable paste (Metapaste; Meta Biomed) with ratio of 1:2, to allow for better handling [16]. After continuous stirring, they soon became totally miscible in each other.

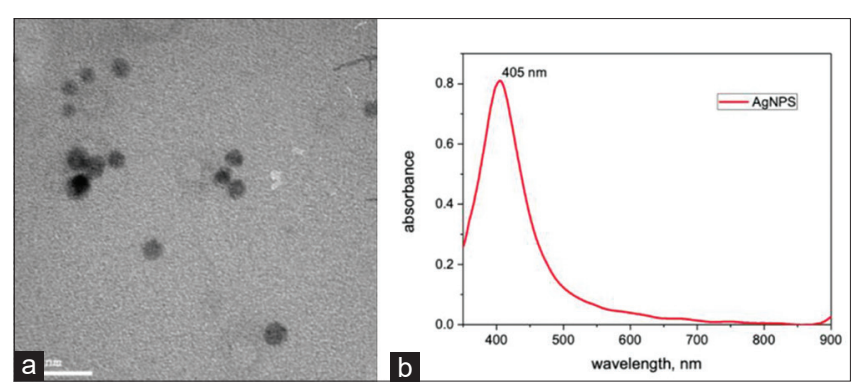

Figure 1: Characterization of silver nanoparticles. (a) TEM image taken for the silver nanoparticles at magnification scale $50 \mathrm{~nm}$. (b) Absorption rate curve of silver nanoparticles solution 


\section{Clinical procedures}

Before treatment, diagnosis of the case was performed including electric pulp testing, percussion, palpation, mobility, periodontal assessment, and radiographic examination. The same operator completed treatment of all cases in two visits as follows:

Each patient was given pain scale chart (modified VAS scale) to record his/her pain level before treatment to ensure the absence of pain. Each tooth was anesthetized using infiltration technique (4\% articaine with 1:100,000 epinephrine) (Artinibsa; Inibsa). Each tooth was thoroughly cleaned, and any caries/ restoration was removed with sterile burs. Rubber dam was applied, and the operative field was disinfected with $3 \%$ hydrogen peroxide and $2.5 \%$ sodium hypochlorite $(\mathrm{NaOCl})$ for $1 \mathrm{~min}$ each followed by $5 \mathrm{ml}$ of $5 \%$ sodium thiosulfate to inactivate the $\mathrm{NaOCl}$ for $30 \mathrm{~s}$. The sterility of the operative field was checked by smearing a swab taken from the operative field on blood agar plates. The access cavity was then prepared with another sterile round bur size 3 and Endo-Z Bur (Dentsply Maillefer). The operative field and pulp chamber were disinfected once again in the same manner described above. The patency of the root canals was confirmed using stainless steel hand K-files size \#10 or \#15 (MANI). Working length was determined using an apex locator (Root ZX; J. Morita) then confirmed radiographically to be $1 \mathrm{~mm}$ shorter than radiographic apex. Debridement was performed with the initial file along with $2 \mathrm{ml}$ of $0.9 \%$ sterile saline solution. The pre-instrumentation root canal samples (S1) were taken as follows; three sterile paper points size \#15 (Meta Biomed) were consecutively placed in the canal without any irrigation to soak up the fluid in the canal to the working length. Each paper point was left in the canal for 1 min then transferred aseptically to sterile tubes containing $20 \mathrm{ml}$ of sterile thioglycolate broth [17].

Mechanical preparation was performed using rotary files (Revo-S; Micro-Mega) until file AS40. The canal was irrigated using $3 \mathrm{ml} 2.5 \% \mathrm{NaOCl}$ and recapitulated after the use of each instrument. EDTA gel (MD-ChelCream; Meta Biomed) was used as a lubricant. Finally, the canal was thoroughly irrigated with $5 \mathrm{ml} 2.5 \% \mathrm{NaOCl}$ using a plastic disposable syringe with side-vented needle with a gauge 30 (Endo-EZE; Ultradent), then dried with sterile paper points followed by $5 \mathrm{ml}$ of $5 \%$ sodium thiosulfate and finally flushed with $5 \mathrm{ml}$ of $0.9 \%$ sterile saline solution.

The post-instrumentation root canal samples (S2) were taken from the canals as described for preinstrumentation root canal sample. The microbiological samples were sent to the microbiology laboratory, Department of Microbiology, Faculty of Medicine, Cairo University, within $15 \mathrm{~min}$ of sampling to detect the number of colony-forming units $/ \mathrm{ml}$ (CFUs/ml). In the intervention and control groups, $1 \mathrm{ml}$ of the tested intracanal medications were placed inside the canals using sterile plastic syringe with needle gauge 30 adjusted to the working length. The access cavities were closed using a dry sterile cotton pellet and Fuji IX (GC).

The second appointment was scheduled after 7 days. Rubber dam was applied followed by the same disinfection protocol mentioned previously and removal of the restoration and intracanal medications by irrigation with $10 \mathrm{ml}$ of $0.9 \%$ sterile saline. The post-intracanal medication sample (S3) was taken from the canal. The rotary master apical file AS40 was used to ensure removal of all intracanal medications accompanied with $5 \mathrm{ml} 2.5 \% \mathrm{NaOCl}$ followed by $2 \mathrm{ml}$ $17 \%$ EDTA. Finally, the canals were flushed with $10 \mathrm{ml}$ of $0.9 \%$ sterile normal saline and dried with sterile paper points. Obturation was completed using lateral compaction technique with resin-based root canal sealer (AdSeal; Meta Biomed). The access cavities were restored with composite resin (Ceram.x; Dentsply Sirona) and occlusal contact was checked.

\section{Pain assessment}

Patients were asked to record their pain level after both visits on a modified VAS at 4, 24, 48, 72, and $96 \mathrm{~h}$. Pain level was assigned to one of four categorical scores: 1, None (0); 2, mild (1-3); 3, moderate (4-6); and 4, severe (7-10) [18]. The patients were instructed to contact the outcome assessor in case of unbearable pain and were given 400 mg ibuprofen (Brufen; Abbott) [19].

\section{Statistical methods}

For pain records, Kruskal-Wallis and Fisher's exact tests were used to compare between tested groups followed by Friedman test used to assess the changes by time. For bacterial count, logarithmic transformation was done to achieve normal distribution. Kruskal-Wallis and Friedman tests were used to compare between tested groups while for the percentage of bacterial reduction, ANOVA test was used.

\section{Results}

Thirty patients were recruited with recall rate of $100 \%$ (Figure 2). There was no significant difference between the groups regarding the following baseline characteristics: Age and sex (Table 1). For the incidence of pain, there was a significant difference at $24(p=0.005)$ and $48 \mathrm{~h}(p=0.001)$ after the first visit when comparing the three groups. Regarding the severity of pain, the $\mathrm{Ca}(\mathrm{OH})_{2}+$ AgNPs group showed the highest prevalence of severe and moderate pain at $24 \mathrm{~h}(\mathrm{p}=0.006)$ and $48 \mathrm{~h}(\mathrm{p}=0.002)$ interappointment while $30-40 \%$ of the patients experienced no pain. 


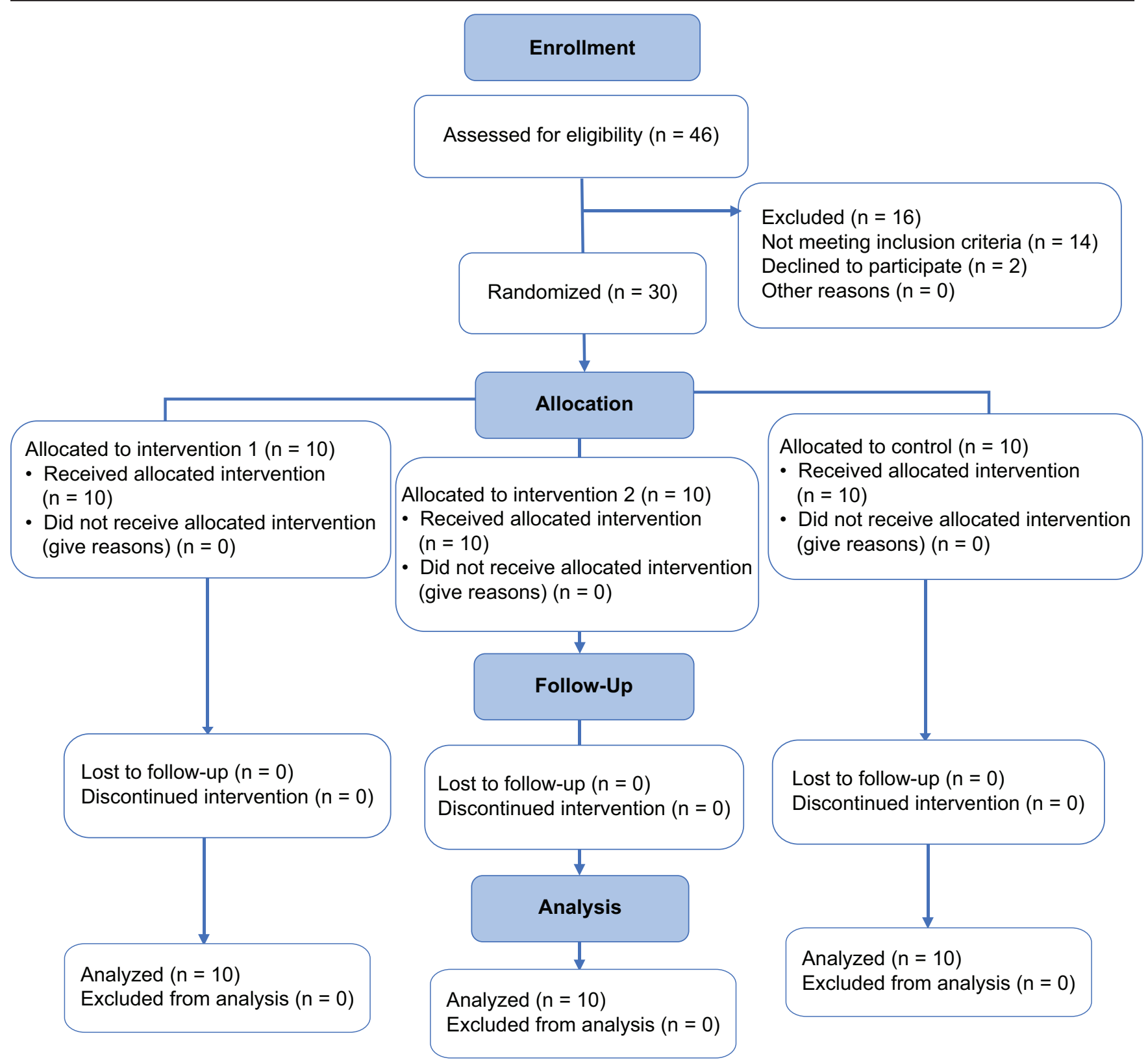

Figure 2: A consolidated standards of reporting trials flow diagram of the trial

For the remaining follow-up periods, there was a statistically insignificant difference in the incidence and severity of pain when comparing the three groups either at 4, 72, and $96 \mathrm{~h}$ interappointment or at 4, 24, and $48 \mathrm{~h}$ postoperatively. After 72 as well as $96 \mathrm{~h}$, all cases in the three groups had no pain, so no statistical comparison was performed (Table 2).

Table 1: Mean, standard deviation (SD), frequencies (n), percentages (\%), and results of one-way ANOVA test and Fisher's exact test for comparisons of demographic data in the three groups

\begin{tabular}{lllll}
\hline Demographic data & $\mathrm{Ca}(\mathrm{OH})_{2}(\mathrm{n}=10)$ & AgNPs $(\mathrm{n}=10)$ & $\begin{array}{l}\mathrm{Ca}(\mathrm{OH})_{2}{ }^{+} \\
\operatorname{AgNPs}(\mathrm{n}=10)\end{array}$ & $\mathrm{p}$ value \\
\hline $\begin{array}{l}\text { Age (years) } \\
\text { Mean (SD) }\end{array}$ & $29.9(4.5)$ & $28(6.1)$ & $31.1(3.8)$ & 0.372 \\
$\begin{array}{l}\text { Sex }(\mathrm{n}[\%]) \\
\quad \text { Male }\end{array}$ & $6(60)$ & $5(50)$ & $5(50)$ & 1.00 \\
$\quad$ Female & $4(40)$ & $5(50)$ & $5(50)$ & \\
*: Significant at $\mathrm{p} \leq 0.05$. & & & &
\end{tabular}

Concerning the intracanal aerobic bacterial count, there was a significant difference between median $\log _{10}$ CFUs of bacteria post-instrumentation (S2) $(p=0.048)$. For the post-intracanal medication sample (S3), there was no significant difference between median $\log _{10}$ CFUs of aerobic bacteria in the three groups $(p=0.147)$ (Table 3 ).

For the anaerobic bacteria, there was no statistically significant difference between the three groups post-instrumentation (S2) $(p=0.408)$, whereas post-intracanal medication (S3); there was a statistically significant difference between median Log $_{10}$ CFUs in the three groups $(p<0.001) . \mathrm{Ca}(\mathrm{OH})$, group showed a significantly highest median $\log _{10}$ CFUs, while both AgNPs and $\mathrm{Ca}(\mathrm{OH})_{2}+$ AgNPs groups showed lowest median $\log _{10}$ CFUs with no significant difference between them (Table 3). 
Table 2: Descriptive statistics and results of Fisher's exact test for comparison between intensity of pain in the three groups

\begin{tabular}{|c|c|c|c|c|c|c|c|}
\hline \multirow[t]{2}{*}{ Time (hours) } & \multicolumn{2}{|c|}{$\mathrm{Ca}(\mathrm{OH})_{2}(\mathrm{n}=10)$} & \multicolumn{2}{|c|}{$\mathrm{AgNP}_{\mathrm{s}}(\mathrm{n}=10)$} & \multicolumn{2}{|c|}{$\begin{array}{l}\mathrm{Ca}(\mathrm{OH})_{2}+ \\
\mathrm{AgNP}_{\mathrm{s}} \\
(\mathrm{n}=10)\end{array}$} & \multirow[t]{2}{*}{$p$ value } \\
\hline & $\mathrm{n}$ & $\%$ & $\mathrm{n}$ & $\%$ & $\mathrm{n}$ & $\%$ & \\
\hline \multicolumn{8}{|l|}{ Interappointment Pain } \\
\hline \multicolumn{8}{|l|}{$4 \mathrm{~h}$} \\
\hline No pain & 10 & 100 & 10 & 100 & 9 & 90 & 1.00 \\
\hline Severe pain & 0 & 0 & 0 & 0 & 1 & 10 & \\
\hline \multicolumn{8}{|l|}{$24 \mathrm{~h}$} \\
\hline No pain & 10 & 100 & 8 & 80 & 4 & 40 & $.006^{*}$ \\
\hline Moderate pain & 0 & 0 & 2 & 20 & 2 & 20 & \\
\hline Severe pain & 0 & 0 & 0 & 0 & 4 & 40 & \\
\hline \multicolumn{8}{|l|}{$48 \mathrm{~h}$} \\
\hline No pain & 10 & 100 & 9 & 90 & 3 & 30 & $.002^{*}$ \\
\hline Mild pain & 0 & 0 & 1 & 10 & 5 & 50 & \\
\hline Moderate pain & 0 & 0 & 0 & 0 & 2 & 20 & \\
\hline \multicolumn{8}{|l|}{$72 \mathrm{~h}$} \\
\hline No pain & 10 & 100 & 10 & 100 & 8 & 80 & .310 \\
\hline Mild pain & 0 & 0 & 0 & 0 & 1 & 10 & \\
\hline Moderate pain & 0 & 0 & 0 & 0 & 1 & 10 & \\
\hline \multicolumn{8}{|l|}{$96 \mathrm{~h}$} \\
\hline No pain & 10 & 100 & 10 & 100 & 9 & 90 & 1.00 \\
\hline Mild pain & 0 & 0 & 0 & 0 & 1 & 10 & \\
\hline \multicolumn{8}{|l|}{ Post-operative pain } \\
\hline \multicolumn{8}{|l|}{$4 \mathrm{~h}$} \\
\hline No pain & 10 & 100 & 10 & 100 & 9 & 90 & 1.00 \\
\hline Moderate pain & 0 & 0 & 0 & 0 & 1 & 10 & \\
\hline \multicolumn{8}{|l|}{$24 \mathrm{~h}$} \\
\hline No pain & 10 & 100 & 8 & 80 & 9 & 90 & .754 \\
\hline Mild pain & 0 & 0 & 1 & 10 & 0 & 0 & \\
\hline Moderate pain & 0 & 0 & 1 & 10 & 1 & 10 & \\
\hline \multicolumn{8}{|l|}{$48 \mathrm{~h}$} \\
\hline No pain & 10 & 100 & 10 & 100 & 9 & 90 & 1.000 \\
\hline Mild pain & 0 & 0 & 0 & 0 & 1 & 10 & \\
\hline \multicolumn{8}{|l|}{$72 \mathrm{~h}$} \\
\hline No pain & 10 & 100 & 10 & 100 & 10 & 100 & Not computed \\
\hline \multicolumn{8}{|l|}{$96 \mathrm{~h}$} \\
\hline No pain & 10 & 100 & 10 & 100 & 10 & 100 & Not computed \\
\hline
\end{tabular}

Comparing the percentage reduction in bacterial count in the three groups; for the aerobic intracanal bacterial, there was no statistically significant difference between mean percentage reduction in the three groups either post-instrumentation $(p=0.303)$ or post-intracanal medication $(p=0.174)$. On the other hand, there was a statistically significant difference between mean percentage reductions in anaerobic bacterial counts post-intracanal medication in the three groups $(p<0.001)$. Insignificant difference between AgNPs alone and $\mathrm{Ca}(\mathrm{OH})_{2}+$ AgNPs groups; both showed significantly higher mean percentage reduction than the control group (Figure 3).

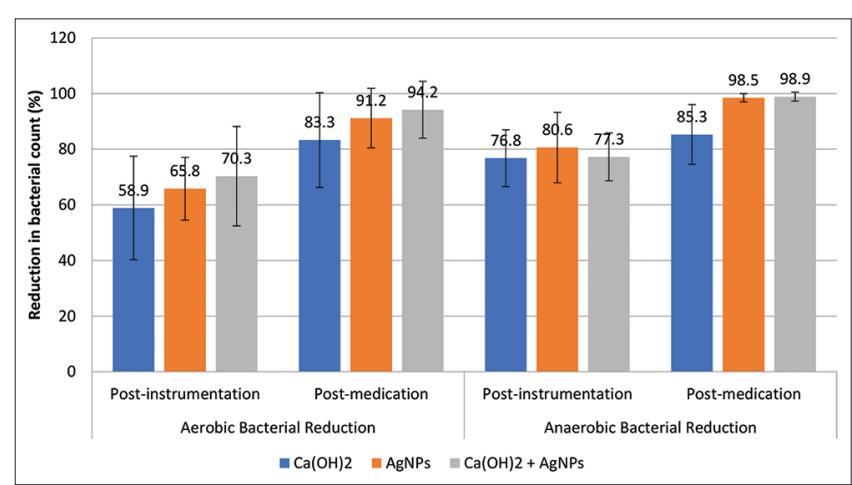

Figure 3: Bar chart representing mean and standard deviation values for percentage reduction in aerobic and anaerobic bacterial counts in the three groups

$\mathrm{Ca}(\mathrm{OH})_{2}$ or AgNPs are effective intracanal medications in reducing the incidence and severity of interappointment and post-operative pain. $\mathrm{Ca}(\mathrm{OH})_{2}$ + AgNPs or AgNPs alone were more effective against anaerobic bacteria than the use of $\mathrm{Ca}(\mathrm{OH})_{2}$ alone. $\mathrm{Ca}(\mathrm{OH})_{2}$ used in this study was not able to eliminate bacteria present in canals and showed significantly less antimicrobial action compared with other tested medications. Thus, the null hypotheses were rejected.

\section{Discussion}

Pain is a challenging outcome to assess due to its complex and subjective nature, however, patients' self-assessment reports provide the most valid measure of pain experience [20]. Several pain scales; numerical, verbal, and VAS are used in clinical studies [21]. In this study, the modified VAS was applied which is widely utilized in the endodontic literature due to its simplicity, high reliability, repeatability, validity, and sensitivity to small changes than descriptive ordinal scales [22], [23], [24], [25].

Table 3: Descriptive statistics and results of Kruskal-Wallis test for comparison between $\log _{10}$ CFU of bacteria in the three groups

\begin{tabular}{|c|c|c|c|c|c|}
\hline & $\mathrm{Ca}(\mathrm{OH})_{2}(\mathrm{n}=10)$ & $\operatorname{AgNPs}(n=10)$ & $\mathrm{Ca}(\mathrm{OH})_{2}+\mathrm{AgNPs}(\mathrm{n}=10)$ & $p$ value & Effect size (eta squared) \\
\hline \multicolumn{6}{|l|}{ Aerobic bacterial count } \\
\hline Pre-instrumentation & & & & 0.068 & 0.125 \\
\hline Median (range) Log & $1.13(0.7-1.9)$ & $1.04(0.7-1.4)$ & $0.95(0.48-1.18)$ & & \\
\hline Mean (SD) $\log _{10}$ & $1.17(0.32)$ & $1.05(0.19)$ & $0.89(0.22)$ & & \\
\hline Post-instrumentation & & & & $0.048^{*}$ & 0.151 \\
\hline Median (range) $\log _{10}$ & $0.77(0.3-1)^{A}$ & $0.54(0.3-0.95)^{\mathrm{B}}$ & $0.48(0-0.95)^{\mathrm{B}}$ & & \\
\hline Mean (SD) $\log _{10}$ & $0.73(0.26)$ & $0.57(0.2)$ & $0.42(0.29)$ & & \\
\hline Post-medication & & & & 0.147 & 0.068 \\
\hline Median (range) Log $_{10}$ & $0.39(0-1.6)$ & $0(0-0.6)$ & $0(0-0.6)$ & & \\
\hline Mean (SD) $\log _{10}$ & $0.43(0.5)$ & $0.19(0.25)$ & $0.11(0.23)$ & & \\
\hline \multicolumn{6}{|l|}{ Anaerobic bacterial count } \\
\hline Pre-instrumentation & & & & 0.566 & 0.032 \\
\hline Median (range) Log $_{10}$ & $1.7(1.4-1.95)$ & $1.65(1.4-1.85)$ & $1.54(1.4-1.85)$ & & \\
\hline Mean (SD) $\log _{10}$ & $1.66(0.19)$ & $1.65(0.16)$ & $1.59(0.16)$ & & \\
\hline Post-instrumentation & & & & 0.408 & 0.008 \\
\hline Median (range) Log & $1(0.7-1.3)$ & $0.85(0.3-1.3)$ & $0.95(0.7-1.26)$ & & \\
\hline Mean (SD) $\log _{10}$ & $0.99(0.18)$ & $0.86(0.29)$ & $0.91(0.18)$ & & \\
\hline Post-medication & & & & $<0.001^{*}$ & 0.613 \\
\hline Median (range) Log $_{10}$ & $0.87(0-1)^{A}$ & $0(0-0.3)^{\mathrm{B}}$ & $0(0-0)^{B}$ & & \\
\hline Mean (SD) $\log _{10}$ & $0.69(0.37)$ & $0.03(0.1)$ & $0(0)$ & & \\
\hline
\end{tabular}

Significant at $\mathrm{p} \leq 0.05$, different superscripts in the same row are statistically significantly different according to Dunn's test. 
The study design was chosen to be a randomized, double-blind, controlled clinical trial. In attempt to eliminate selection and allocation bias, randomization was applied to control the confounding factors and ensure balance of known and unknown prognostic factors among participants. In addition, the participants and outcome assessors were blinded to the intracanal medication used to reduce performance and ascertainment bias [26].

Pain assessment started $4 \mathrm{~h}$ postoperatively to ensure that the effect of local anesthetic agent is worn off completely [27]. The additional follow-up periods were chosen to assess the periapical inflammation that ensues treatment, leading to firing of proprioceptive nerve fibers in the periodontal ligament resulting in postoperative pain which fades within $24-48$ h [28]. The incidence and severity of post-operative pain is highest in the first $24 \mathrm{~h}$ and decreases substantially to minimal levels [29]. However, pain assessment continued up to 4 days to assess the incidence of flare-up which is defined as moderate-to-severe post-operative pain and/or swelling that begins 12-48 $\mathrm{h}$ after treatment [30], [31].

The results indicated that $\mathrm{Ca}(\mathrm{OH})_{2}$ did not elicit any pain throughout all the follow-up periods. Meanwhile, there is no clear evidence of its influence on reduction of post-operative pain as the available studies are insufficient [5], [6]. Both $\mathrm{Ca}(\mathrm{OH})_{2}$ or AgNPs groups showed statistically significantly lower median pain scores with no statistically significant difference between them. This came in contradiction with an earlier study that found significantly lower pain scores in the AgNPs group at 4,12 , and $24 \mathrm{~h}$ in comparison to $\mathrm{Ca}(\mathrm{OH})_{2}$, while at $48 \mathrm{~h}$ postoperatively, there was no statistically significant difference [9]. A possible explanation may be due to the presence of pre-operative pain at the start of the study mentioned above, which can affect the levels of post-operative pain [32]

While $\mathrm{Ca}(\mathrm{OH})_{2}$ and AgNPs displayed statistically significant lower pain scores when tested individually, when both were combined, the interappointment pain was elicited and intensified. This could be attributed to, the high surface area per unit mass, chemical composition and surface properties of nanoparticles which are factors that can induce toxicity, however, this has a low probability of occurring due to the low concentration and small particle size used in the current study [33]. To the best of our knowledge, this is the first study to compare the post-operative pain of combining $\mathrm{Ca}(\mathrm{OH})_{2}$ and AgNPs, hence, the exact mechanism of action of this mixture is yet to be fully understood

The antibacterial effect on the aerobic and anaerobic intracanal bacterial counts was assessed by microbiological sampling, culture, and counting of CFUs/ml. Despite its limitations, it is considered the gold standard and a well-established protocol in clinical trials as it gives an indication about the usefulness of a treatment procedure on bacterial elimination [34]. Meanwhile, a negative culture does not indicate that the canals are rendered free of bacteria, but it implies that the number of bacteria was lower than a certain threshold level that it gave a negative culture [35]. Consequently, evaluating the antimicrobial efficacy of any intervention should be assessed for its ability to reduce intracanal bacteria [36].

In most in vitro studies, the antimicrobial efficacy of various intracanal medications has been tested against $E$. faecalis biofilm. Although it is the most prevalent species found in most cases of persistent intraradicular infections, infected canals usually contain more than one species of microorganism. Consequently, a medication effective against $E$. faecalis in vitro might not necessarily be effective against polymicrobial clinical endodontic infection [10].

Although $\mathrm{Ca}(\mathrm{OH})_{2}$ is a widely used intracanal medication, it does not affect all bacteria found in the root canal uniformly. Several studies have reported that $\mathrm{Ca}(\mathrm{OH})_{2}$ failed to effectively eliminate enterococci, due to their tolerance to high $\mathrm{pH}$ values, ranging from 9 to 11 compared to that of other bacterial species. They attributed the low antibacterial activity of $\mathrm{Ca}(\mathrm{OH})_{2}$ to its affection to the buffering property of dentine [37].

Nowadays, AgNPs are being incorporated in various medical and dental materials and devices because of its inhibitory effects on the growth of microorganisms. The specific antibacterial mechanism of AgNPs is not yet clear; however, several mechanisms were proposed including interacting with cell wall and membrane causing lysis, disturbing protein synthesis, or inhibiting DNA replication [7].

The antibacterial effect of the mixture of $\mathrm{Ca}(\mathrm{OH})_{2}+$ AgNPs is comparable to that found in several studies [11], [16], [38]. The exact mechanism of the antibacterial activity of the mixture of $\mathrm{Ca}(\mathrm{OH})_{2}+$ AgNPs is yet to be fully understood. Researchers related the antibacterial effect of AgNPs to the concentration used and mode of application. The application of a $0.02 \%$ AgNPs gel as a medication resulted in a significant disruption of $E$. faecalis biofilm compared to $\mathrm{Ca}(\mathrm{OH})_{2}$ [39]. In the current study, both interventions were of a gel form and a low concentration of $0.03 \mu \mathrm{g} / \mathrm{ml}$ AgNPs was tested.

The three groups; $\mathrm{Ca}(\mathrm{OH})_{2}$, AgNPs, and $\mathrm{Ca}(\mathrm{OH})_{2}+$ AgNPs showed an overall mean aerobic bacterial reduction of $83.3 \%, 91.2 \%$, and $94.2 \%$, respectively. Although the percentage of aerobic bacterial reduction increased from 58-70\% postinstrumentation to $83-94 \%$ post-intracanal medication, there was no significant difference. Similar results were reported in several studies [35], [40], [41]. It could be assumed that with increasing the sample size, the significance would become obvious.

Meanwhile, there was a statistically significant difference between mean percentage reduction in 
anaerobic bacterial counts in the three groups postintracanal medication with no significant difference between AgNPs and $\mathrm{Ca}(\mathrm{OH})_{2}+$ AgNPs groups; both showed significantly higher mean percentage reduction in anaerobic bacteria than $\mathrm{Ca}(\mathrm{OH})_{2}$ alone group. This coincides with results from the previous studies where the combination group was the most effective medication in root canals contaminated with $E$. faecalis bacteria [10], [11]. Similar particle sizes showed a bactericidal efficacy against both Gram-positive and -negative bacteria [42], [43], [44], as well as an inhibitory effect on multidrug-resistant organisms [45].

Finally, it is worth mentioning the limitations of this study. Only one concentration of AgNPs and one ratio of $\mathrm{Ca}(\mathrm{OH})_{2}$ to AgNPs were used, which may impact post-operative pain and antibacterial efficacy. Further studies should include different concentrations and ratios.

\section{Conclusions}

Within the limitations of the study, it can be concluded that combined $\mathrm{Ca}(\mathrm{OH})_{2} /$ AgNPs $(0.03 \mu \mathrm{g} /$ $\mathrm{ml}$ concentration) in the ratio of $2: 1$ reduced the intracanal bacterial counts significantly more than each one alone. Meanwhile, it adversely affected the incidence and severity of interappointment pain. The present study highlights the effective application of AgNPs for endodontic disinfection and the potential advantage of using a mixture of $\mathrm{Ca}(\mathrm{OH})_{2}$ and AgNPs for intracanal medication. Based on that finding, this combination should be tested in different concentrations with different ratios to reach the most effective combination that may create a new horizon in endodontic therapy.

\section{References}

1. Siqueira JF. Microbial causes of endodontic flareups. Int Endod J. 2003;36(7):453-63. https://doi org/10.1046/j.1365-2591.2003.00671.x PMid: 12823700

2. Devakar R, Malarvizhi D, Mitthra S, Prakash V. An update of pain management in endodontic flare-ups: A review. Indian J Public Health Res Dev. 2019;10(11):3011-3. https://doi. org/10.5958/0976-5506.2019.04366.3

3. Hermann B. Calcium Hydroxide as a Means for Treating and Filling Tooth Root Canals, Dr Thesis; 1920. p. 29.

4. Kim D, Kim E. Antimicrobial effect of calcium hydroxide as an intracanal medicament in root canal treatment: A literature review-Part II. In vivo studies. Restor Dent Endod. 2015;40(2):97103. https://doi.org/10.5395/rde.2015.40.2.97

PMid:25984470
5. Anjaneyulu K, Nivedhitha MS. Influence of calcium hydroxide on the post-treatment pain in Endodontics: A systematic review. J Conserv Dent. 2014;17(3):200-7. https://doi. org/10.4103/0972-0707.131775

PMid:24944439

6. Ibrahim AM, Zakhary SY, Amin SA. Calcium hydroxide intracanal medication effects on pain and flare-up: A systematic review and meta-analysis. Restor Dent Endod. 2020;45(3):e26. https://doi. org/10.5395/rde.2020.45.e26

PMid:32839707

7. Fernandez CC, Sokolonski AR, Fonseca MS, Stanisic D, Araújo DB, Azevedo V, et al. Applications of silver nanoparticles in dentistry: Advances and technological innovation. Int $\mathrm{J} \mathrm{Mol}$ Sci. 2021;22(5):2485. https://doi.org/10.3390/ijms22052485 PMid:33801230

8. Wong J, Zou T, Lee AHC, Zhang C. The potential translational applications of nanoparticles in endodontics. Int J Nanomedicine. 2021;16:2087-106

PMid:33727815

9. El Abbasy FE, Ibrahim S, Shaker O, Ahmed G. Intra-canal medication containing silver nanoparticle versus calcium hydroxide in reducing postoperative pain: A randomized clinical trial. F1000Research. 2018;7:1949. https://doi.org/10.12688/ f1000research.17199.1

10. Afkhami F, Pourhashemi SJ, Sadegh M, Salehi Y, Fard MJ. Antibiofilm efficacy of silver nanoparticles as a vehicle for calcium hydroxide medicament against Enterococcus faecalis. J Dent. 2015;43(12):1573-9. https://doi.org/10.1016/j. jdent.2015.08.012

PMid:26327612

11. Javidi M, Afkhami F, Zarei M, Ghazvini K, Rajabi O. Efficacy of a combined nanoparticulate/calcium hydroxide root canal medication on elimination of Enterococcus faecalis. Aust Endod J. 2014;40(2):61-5. https://doi.org/10.1111/aej.12028 PMid:25244219

12. Balto $\mathrm{H}$, Bukhary $\mathrm{S}, \mathrm{Al}-$ Omran $\mathrm{O}$, BaHammam $\mathrm{A}$, Al-Mutairi $\mathrm{B}$. Combined effect of a mixture of silver nanoparticles and calcium hydroxide against Enterococcus faecalis biofilm. J Endod. 2020;40(10):880-5. https://doi.org/10.1016/j.joen.2020.07.001 PMid:32679241

13. Singh RD, Khatter R, Bal RK, Bal CS. Intracanal medications versus placebo in reducing postoperative endodontic pain: A double-blind randomized clinical trial. Braz Dent J. 2013;24(1):25-9. https://doi.org/10.1590/0103-6440201302039 PMid:23657409

14. Tak WS, Kim DJ, Ryu SC. Preparation and properties of hydroxyapatite/methylcellulose for bone graft. J Korean Ceram Soc. 2018;55(2):145-52. https://doi.org/10.4191/ kcers.2018.55.2.12

15. Xinping L, Shengli L, Miaotao Z, Wenlong Z, Chuanghong L. Evaluations of antibacterial activity and cytotoxicity on ag nanoparticles. Rare Metals Mater Eng. 2011;40(2):209-14. https://doi.org/10.1016/s1875-5372(11)60017-9

16. Alabdulmohsen Z, Saad A. Antibacterial effect of silver nanoparticles against Enterococcus faecalis. Saudi Endod J. 2017;7(1):29-35. https://doi.org/10.4103/1658-5984.197989

17. Siqueira JF, Paiva SS, Rôças IN. Reduction in the cultivable bacterial populations in infected root canals by a chlorhexidinebased antimicrobial protocol. J Endod. 2007;33(5):541-7. https://doi.org/10.1016/j.joen.2007.01.008 PMid: 17437868

18. Jalalzadeh SM, Mamavi A, Shahriari S, Santos FA, Pochapski MT. Effect of pretreatment prednisolone on postendodontic pain: A double-blind parallel-randomized clinical trial. J Endod. 2010;36(6):978-81. https://doi.org/10.1016/j. 
joen.2010.03.015

PMid:20478449

19. Derry CJ, Derry S, Moore RA, McQuay HJ. Single dose oral ibuprofen for acute postoperative pain in adults. Cochrane Database Syst Rev. 2009;3:CD001548. https://doi. org/10.1002/14651858.cd001548.pub2

PMid:19588326

20. Sadaf $D, A$ Amad MZ. Factors associated with postoperative pain in endodontic therapy. Int J Biomed Sci. 2014;10(4):243-47. PMid:25598754

21. Phan N, Blome C, Fritz F, Gerss J, Reich A, Ebata T, et al. Assessment of pruritus intensity: Prospective study on validity and reliability of the visual analogue scale, numerical rating scale and verbal rating scale in 471 patients with chronic pruritus. Acta Derm Venereol. 2012;92(5):502-7. https://doi. org/10.2340/00015555-1246

PMid:22170091

22. EIMubarak $\mathrm{AH}$, Abu-bakr NH, Ibrahim YE. Postoperative pain in multiple-visit and single-visit root canal treatment. J Endod. 2010;36(1):36-9. https://doi.org/10.1016/j.joen.2009.09.003 PMid:20003932

23. Torabinejad $M$, Shabahang $S$, Bahjiri K. Effect of MTAD on postoperative discomfort: A randomized clinical trial J Endod. 2005;31(3):171-6. https://doi.org/10.1097/01. don.0000137642.50944.a2 PMid: 15735462

24. Ali S, Mulay S, Palekar A, Sejpal D, Joshi A, Gufran H. Prevalence of and factors affecting post-obturation pain following single visit root canal treatment in Indian population: A prospective, randomized clinical trial. Contemp Clin Dent. 2012;3(4):459-63. https://doi.org/10.4103/0976-237x.107440 PMid:23633809

25. Holdgate A, Asha S, Craig J, Thompson J. Comparison of a verbal numeric rating scale with the visual analogue scale for the measurement of acute pain. Emerg Med (Fremantle). 2003;15(56):441-6. https://doi.org/10.1046/j.1442-2026.2003.00499.x PMid:14992058

26. Chan AW, Tetzlaff JM, Gotzsche PC, Altman DG, Mann H, Berlin JA, et al. SPIRIT 2013 explanation and elaboration: Guidance for protocols of clinical trials. BMJ. 2013;346(15):e7586. https://doi.org/10.1136/bmj.e7586 PMid:23303884

27. Becker DE, Reed KL. Local anesthetics: Review of pharmacological considerations. Anesth Prog. 2012;59(2):90101; quiz 102-3.

PMid:22822998

28. Seltzer S, Naidorf IJ. Flare-ups in endodontics: II. Therapeutic measures. J Endod. 2004;30(7):482-8; discussion 475. https:// doi.org/10.1097/00004770-200407000-00006 PMid:15220642

29. Pak JG, White SN. Pain prevalence and severity before, during, and after root canal treatment: A systematic review. $J$ Endod. 2011;37(4):429-38. https://doi.org/10.1016/j. joen.2010.12.016

PMid:21419285

30. Walton R, Fouad A. Endodontic interappointment flareups: A prospective study of incidence and related factors. J Endod. 1992;18(4):172-7. https://doi.org/10.1016/ s0099-2399(06)81413-5

PMid:1402571

31. Pickenpaugh L, Reader A, Beck M, Meyers W, Peterson L. Effect of prophylactic amoxicillin on endodontic flare-up in asymptomatic, necrotic teeth. J Endod. 2001;27(1):53-6. https:// doi.org/10.1097/00004770-200101000-00019

PMid:11487166

32. Alí A, Olivieri JG, Duran-Sindreu F, Abella F, Roig M, García-Font M. Influence of preoperative pain intensity on postoperative pain after root canal treatment: A prospective clinical study. J Dent. 2016;45:39-42. https://doi.org/10.1016/j. jdent.2015.12.002

PMid:26678517

33. Gomes-Filho JE, Silva FO, Watanabe S, Cintra LT, Tendoro KV, Dalto LG, et al. Tissue reaction to silver nanoparticles dispersion as an alternative irrigating solution. J Endod. 2010;36(10):1698702. https://doi.org/10.1016/j.joen.2010.07.007

PMid:20850681

34. Ferreira NS, Martinho FC, Cardoso FG, Nascimento GG Carvalho CA, Valera MC. Microbiological profile resistant to different intracanal medications in primary endodontic infections. J Endod. 2015;41(6):824-30. https://doi.org/10.1016/j. joen.2015.01.031

PMid:25892513

35. Sakamoto M, Siqueira JF, Rôças IN, Benno Y. Bacteria reduction and persistence after endodontic treatment procedures. Oral Microbiol Immunol. 2007;22(1):19-23. https:// doi.org/10.1111/j.1399-302x.2007.00315.x

PMid:17241166

36. Hargreaves KM, Berman LH, Rotstein I. Microbiology of endodontic infections. In: Cohen's Pathways of the Pulp. $11^{\text {th }}$ ed. Netherlands: Elsevier; 2015. p. 610-1.

37. Kim D, Kim E. Antimicrobial effect of calcium hydroxide as an intracanal medicament in root canal treatment: Aliterature reviewPart I. In vitro studies. Restor Dent Endod. 2014;39(4):241-52. https://doi.org/10.5395/rde.2014.39.4.241 PMid:25383341

38. Wu D, Fan W, Kishen A, Gutmann J, Fan B. Evaluation of the antibacterial efficacy of silver nanoparticles against Enterococcus faecalis biofilm. J Endod. 2014;40(2):285-90. https://doi.org/10.1016/j.joen.2013.08.022 PMid:24461420

39. Zhang F, Li M, Wei Z, Zhao B. The effect of a combined nanoparticulate/calcium hydroxide medication on the biofilm of Enterococcus faecalis in starvation phase. Shanghai Kou Qiang Yi Xue. 2016;25(1):11-5. PMid:27063301

40. Siqueira J Jr., Guimaraespinto T, Rocas I. Effects of chemomechanical preparation with $2.5 \%$ sodium hypochlorite and intracanal medication with calcium hydroxide on cultivable bacteria in infected root canals. J Endod. 2007;33(7):800-5. https://doi.org/10.1016/j.joen.2006.11.023 PMid: 17804315

41. Shuping G, Orstavik D, Sigurdsson A, Trope M. Reduction of intracanal bacteria using nickel-titanium rotary instrumentation and various medications. J Endod. 2000;26(12):751-5. https:// doi.org/10.1097/00004770-200012000-00022

PMid: 11471648

42. Guzman M, Dille J, Godet S. Synthesis and antibacteria activity of silver nanoparticles against gram-positive and gramnegative bacteria. Nanomedicine. 2012;8(1):37-45. https://doi. org/10.1016/j.nano.2011.05.007

PMid:21703988

43. Morones JR, Elechiguerra JL, Camacho A, Holt K, Kouri JB, Ramírez JT, et al. The bactericidal effect of silver nanoparticles. Nanotechnology. 2005;16(10):2346-53. https://doi. org/10.1088/0957-4484/16/10/059 


\section{PMid:20818017}

44. Wang L, Hu C, Shao L. The antimicrobial activity of nanoparticles: Present situation and prospects for the future. Int J Nanomedicine. 2017;12:1227-49. https://doi.org/10.2147/ijn. s121956

PMid:28243086
45. Rai MK, Deshmukh SD, Ingle AP, Gade AK. Silver nanoparticles: The powerful nanoweapon against multidrug-resistant bacteria. J Appl Microbiol. 2012;112(5):841-52. https://doi. org/10.1111/j.1365-2672.2012.05253.x

PMid:22324439 